\title{
Analysis, design, and creation of a learning program in Big Data at the higher education level: Case study Instituto Tecnológico Superior de Rioverde, SLP
}

\section{Análisis, diseño y creación de un programa de aprendizaje en Big Data a nivel de educación superior: Caso de estudio Instituto Tecnológico Superior de Rioverde, SLP}

MENDOZA-GONZÁLEZ, Omar†*, AMADOR-GARCÍA, Mónica, TORRES-MERAZ, Yurivia and GARCÍA-PADRÓN, Fabiola

Facultad de Estudios Superiores Aragón UNAM, Tecnológico Nacional de México/ITS de Rioverde, SLP

ID $1^{\text {st }}$ Autor: Omar, Mendoza-González / ORC ID: 0000-0002-3492-4549, CVU CONACYT ID: 972783

ID $1^{\text {st }}$ Co-author: Mónica, Amador-García / ORC ID: 0000-0003-3575-9861, CVU CONACYT ID: 450928

ID $2^{\text {nd }}$ Co-author: Yurivia, Torres-Meraz / ORC ID: 0000-0002-7760-6495, CVU CONACYT ID: 1110389

ID $3^{\text {rd }}$ Co-author: Fabiola García Padrón / ORC ID: 0000-0002-0935-5313, CVU CONACYT ID: 1138326

DOI: $10.35429 / J I T C .2021 .13 .5 .9 .13$

Received March 10, 2021; Accepted June 30, 2021

\section{Abstract}

In this paper results of a quantitative and qualitative study are shown to identify interest and acceptance level of Big Data in university students. The creation of a learning program is proposed that will allow students to obtain the necessary knowledge to form a solid foundation regarding Big Data, as well as the necessary tools to start working with this technology. A survey has been carried out of students who study the Educational Programs of Computer Engineering and Engineering in Computer Systems at ITSRV, the results show that $41 \%$ of the respondent's report having zero knowledge of Big Data, $51.28 \%$ mention that it is important to learn about the subject by development professional and the most suitable way, according to the answers, is through a workshop or a certification. Of the eight most used Big Data tools, Hadoop and Spark were the ones identified by the respondents, due to this, and the literature reviewed, it is important that spaces and Big Data learning programs are generated in higher level institutions that allow Students obtain the necessary basic knowledge and identify applications of Big Data in the professional and job context.

Big Data, learning program, Hadoop

\section{Resumen}

En el presente trabajo se realizó un estudio cuantitativo y cualitativo, para identificar el nivel de interés y aceptación en temas de Big Data en estudiantes de nivel superior. Se plantea la creación de un programa de aprendizaje que permitirá a los estudiantes obtener los conocimientos necesarios para formar una base sólida respecto al Big Data, así como las herramientas necesarias para comenzar a trabajar con esta tecnología. Se ha realizado una encuesta a estudiantes que cursan los Programas Educativos de Ingeniería Informática e Ingeniería en Sistemas Computacionales en el ITSRV, los resultados muestran que $41 \%$ de los encuestados informan tener nulo conocimiento de Big Data, $51.28 \%$ mencionan que es importante aprender sobre el tema por desarrollo profesional y la manera más idónea, según las respuestas, es a través un taller o una certificación. De las ocho herramientas de Big Data más utilizadas, Hadoop y Spark fueron las que identificaron los encuestados, debido a ello, y a la literatura revisada, es importante que se generen espacios y programas de aprendizaje de Big Data en instituciones de nivel superior que permitan a estudiantes obtener los conocimientos básicos necesarios e identificar la aplicabilidad de estos temas en el ambiente profesional y laboral.

Big Data, Programa de aprendizaje, Hadoop

Citation: MENDOZA-GONZÁLEZ, Omar, AMADOR-GARCÍA, Mónica, TORRES-MERAZ, Yurivia and GARCÍAPADRÓN, Fabiola. Analysis, design, and creation of a learning program in Big Data at the higher education level: Case study Instituto Tecnológico Superior de Rioverde, SLP. 2021. 5-13: 9-13

\footnotetext{
$\dagger$ Researcher contributing as first author
} 


\section{Introduction}

Nowadays, the amount of information generated in everyday activities has increased considerably. From common activities, such as ordering food at home to checking the state of traffic in a city, continuously generate a large amount of data that must be collected, stored, processed and analyzed.

Different information systems are limited in the capacity to deal with this volume of data, and only storing data is not enough (Becerra, 2015); in addition, many companies do not have a unified solution to collect and analyze data (Escobar \& Mercado, 2019), which can affect proper decision making.

The concept of Big Data allows the management of this type of information thanks to the ability to process large amounts of data quickly and effectively for subsequent analysis, which facilitates decision making (Aguilar, 2013), (Corea, 2019), (Salazar, 2016).

One of the reasons why companies do not benefit from this concept, is due to the lack of qualified professionals in the subject, as mentioned by Elena Gil Lizasoain, CEO of LUCA, Global Big Data Unit at Telefónica (Pontaza, 2019), from here arises the need to provide a space and learning program to train students of the Instituto Tecnológico Superior de Rioverde (ITSRV) in the area of Big Data.

It has been identified that the content of the ITSRV students' curricula does not include subjects that allow them to learn and deepen in the relevant aspects of Big Data. The creation of a learning program will allow students to obtain the necessary knowledge to form a solid base regarding Big Data, as well as the necessary tools to start working with this technology.

Within this document there are sections where you can find the methodology, which corresponds to the description of the method to be used to carry out the project; in the results section, within the analysis from the regression by demand curve, you can observe the degree of acceptance that ITSRV students present to the proposal and finally the learning program suggested as a result of the research is shown; as the last section are the conclusions including future work.

\section{Methodology}

A sample of 39 students was analyzed out of a total of 126, which corresponds to $31 \%$ of the ITSRV Computer Engineering and Computer Systems Engineering careers, it is worth mentioning that this percentage of participation completely covers the minimum required of $10 \%$ of the population to be representative. The study that was applied is quantitative and qualitative, helping to identify elements of current knowledge of Big Data in higher level students, as well as percentages of interest in learning about the subject; a documentary type research was applied that helped to determine the current status of learning about Big Data at the higher level, in addition, the grids of Computer Engineering and Computer Systems Engineering were analyzed, identifying only the inclusion of general topics without going deeper into the subject.

Regarding the instrument, a questionnaire containing 15 items was used, including questions of general knowledge of Databases, Programming, Operating Systems and basic topics of Big Data in addition to options of learning schemes. One of the most widely used self-administered survey methods was used, which is the online questionnaire.

\section{Regression analysis by the demand curve}

According to the survey entitled "Level of interest in the area of Big Data", $41 \%$ of the students report having no knowledge of Big Data, the other $41 \%$ have a low knowledge and only $18 \%$ mention having some knowledge, which is shown in the graph below. 1 .

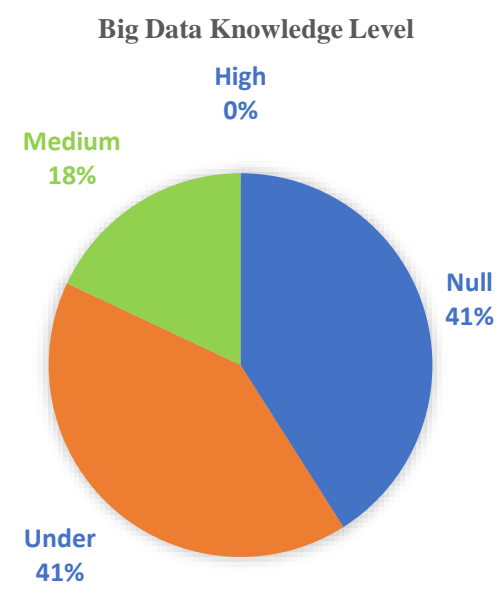

Graph 1 Level of knowledge of Big Data Own Source 
It is highlighted that $51 \%$ of the respondents show a high interest in using Big Data tools, $41 \%$ a medium interest and $8 \%$ a low interest, as shown in Graph 2.

LEVEL of interest in learning how to use Big Data

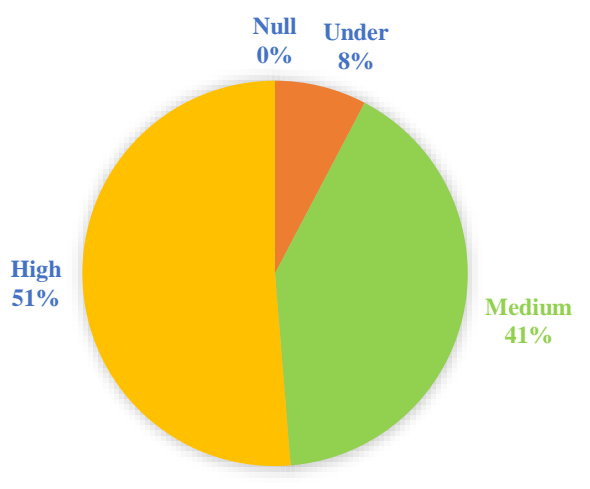

Graph 2 Level of interest in learning how to use Big Data Own Source

$51.28 \%$ of the respondents mentioned that it is important to learn about the topic for professional development, $20.5 \%$ for general knowledge, $10.26 \%$ for updating, another $10.26 \%$ for specialization and the remaining 7.7\% for other reasons, as shown in Graph 3.

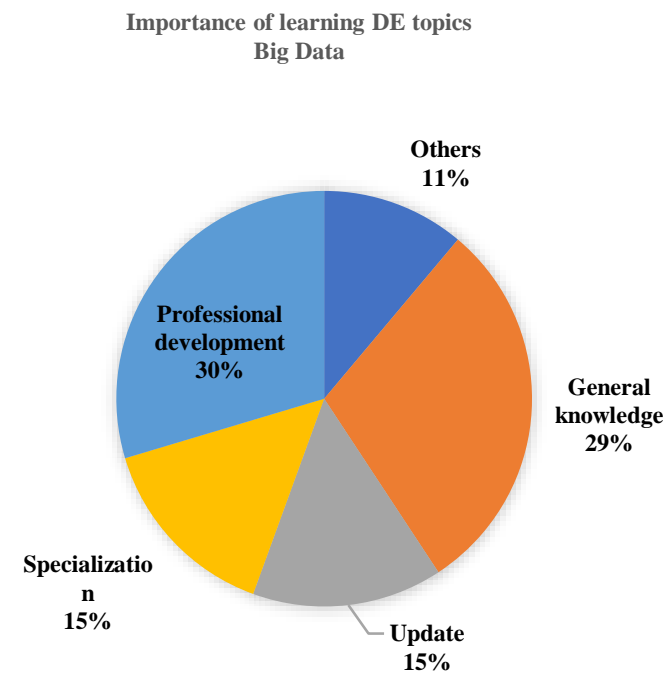

Graph 3 Importance of learning Big Data topics Own Source

Respondents let it be known that the way in which they would be interested in being trained in Big Data topics mostly is through a certification or a workshop, according to the options with the highest choice, as shown in Graph 4.
Form of interest for training in big data

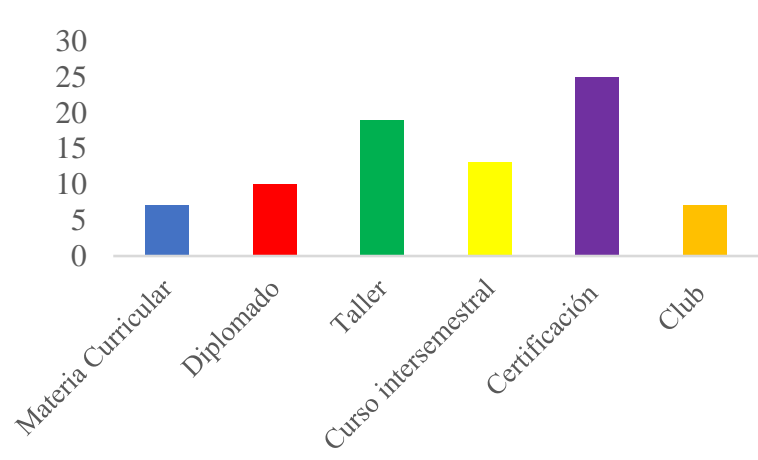

Graph 4 Form of interest to be trained in Big Data Own Source

To determine which tools can be added in the educational program to be proposed, the respondents were asked about the Big Data tools they identify, resulting that most of them recognize Hadoop and Spark, as shown in Graph 5 , they had the option to choose several and the results are shown by number of students.

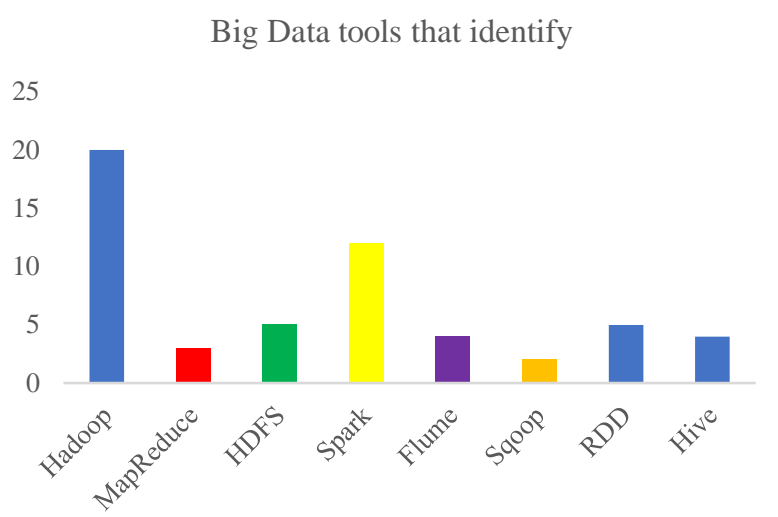

Graph 5 Big Data tools identified by respondents Own Source

Graph 6 shows the degree of knowledge of the different topics, which are identified as important and necessary that the interested party should know before venturing into Big Data, so they are suggested to be part of the content of the program that will remain as a proposal to meet the interest of the students surveyed. 
Level of knowledge of the basic topics of the program content

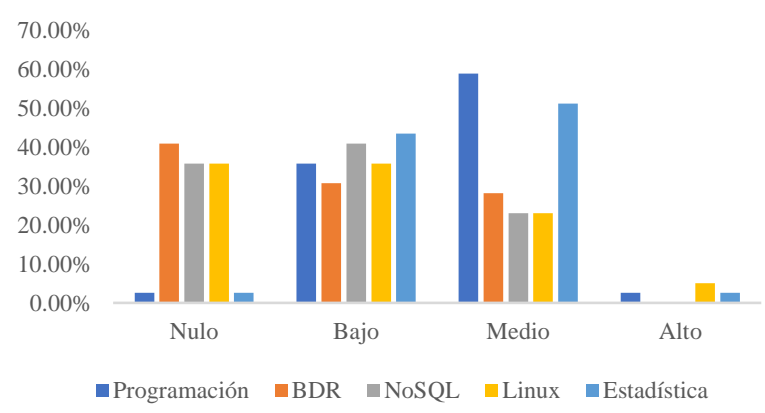

Graph 6 Level of knowledge in the basic topics Own Source

\section{Results}

Big Data encompasses many concepts, tools and technologies, in addition, it is associated with other terms such as Data Science (Hernández et al., 2017), Data Analytics and Data Mining, but the fundamental objective of all of them is to extract value from data. The present proposal focuses on higher level students enrolled in a career related to computer systems and informatics can get to have general training of data processing tools, to operate with large volumes of information, either in batch or fast data streams in real time.

Derived from the survey results, it has been determined that Big Data training programs should include training in:

- $\quad$ Programming languages, essentially some of the most widely used are Python (Caballero et al. 2018) and Java the latter because it is the basis of the Hadoop ecosystem, also another language that is increasingly being incorporated for its versatility to Big Data course programs is Scala, because Storm and Spark allow to operate with it.

Data warehousing, training in both relational and NoSQL databases is important, since Big Data is a concept that refers to the storage of large amounts of data and the procedures used to find repetitive patterns within this data.
- Data processing and storage, the central part in the Big Data training proposed is in data processing, therefore, the Hadoop ecosystem is fundamental (Power Data, 2014), (SAS, n, f), including its distributed processing system (MapReduce) and its distributed file system (HDFS), in addition data ingestion tools such as Sqoop and Flume and storage and analysis tools such as the e Hive.

- $\quad$ In addition, the Apache Spark ecosystem that has taken a great importance in Big Data (Chambers \& Zaharia, 2018), (Holden \& Konwinski, 2015) due to its speed, it is estimated to be one hundred times faster in memory computation and ten times more agile on disk than Hadoop; to the fact that it supports different languages: Scala, Python, $R$ and Java; to the fact that it is very versatile and has a number of interesting tools: Spark SQL, Spark Streaming, MLlib and GraphX.

Data analytics, descriptive and predictive statistics. The Big Data training program should include basic notions about data analysis, mathematical, statistical and methodological foundations of data analysis, and then, in advanced training, include topics such as Machine Learning, Neural Networks, Deep Learning, pattern recognition, predictive models, clustering, etc.

\section{Conclusions}

The results presented in this work show the relevance of including a Big Data learning program at a higher level, in order to contribute to the development of knowledge, competencies and skills of students in the management of huge volumes of information, allowing them as professionals to provide effective solutions to customers and companies. Therefore, the basic content was presented to help achieve this goal. On the other hand, the information derived from the application of the instrument shows the interest of students in learning about Big Data, through various schemes, among the most chosen are: workshop and certification. 
Previous studies also indicate that it is imperative to include thematic content on Big Data in the curriculum of Educational Programs related to the area of Information Technology, Computer Science and Informatics, due to this, the suggestion is derived to incorporate a subject that covers the needs related to the topic in question, as this aspect requires a series of internal procedures, according to the type of institution, it is proposed to start with a workshop that includes the content proposed in the results section.

The implementation of the certification option is not considered adequate for the moment, since it requires the application of specific procedures to validate knowledge on the subject and to be a Certifying Body in the area in question, or to be part of one.

As future work is considered the analysis and generation of a syllabus that includes teaching and learning activities, as well as suggested practices, tools to be used and including competencies to be developed, both specific and generic, focused on Big Data.

\section{References}

Aguilar, L. J. (2013). Big Data de grandes volúmenes de datos en organizaciones. México: Alfaomega.

Becerra, J. L. (2015). https://cio.com.mx. Obtenido de https://cio.com.mx/big-data-queesta-pasando-en-mexico/

Caballero, Roldán Rafael; Marín, Martín Enrique; Riesco, Rodríguez Adrián (2018). Big Data con Python. Recolección, almacenamiento y proceso. Universidad Complutense de Madrid. España: Alfaomega.

Chambers Bill, Zaharia Matei (2018). Spark: The Definitive Guide, EUA: Databricks

Corea, Francesco (2019). An Introduction to Data: Everything You Need to Know About AI, Big Data and Data Science. EUA: Springer

Escobar, Borja Mariana; Mercado, Pérez Margareth. "Big Data: un análisis documental de su uso y aplicación en el contexto de la era digital", Revista La Propiedad Inmaterial, no. 28, julio-diciembre 2019, pp. 273-293.
E.J. Hernández-Leal, N.D. Duque-Méndez y J. Moreno-Cadavid, "Big Data: una exploración de investigaciones, tecnologías y casos de aplicación", TecnoLógicas, vol. 20, no. 39, mayo - agosto, 2017.

Pontaza, Dulce. (2019). "Talento, barrera en la implementación de Big Data en México... y el mundo", https//expansion.mx/, Recuperado 09 de junio 2021. Obtenido de https://expansion.mx/tecnologia/2019/02/21/tal ento-barrera-en-la-implementacion-de-big-dataen-mexico-y-el-mundo

Holden Karau, Andy Konwinski (2015). Learning Spark. EUA: Databricks.

PowerData, R. (2014.). El asombrosamente rico ecosistema de Hadoop. Recuperado 24 de febrero 2021 de https://blog.powerdata.es/elvalor-de-la-gestion-de-datos/bid/390089/elasombrosamente- rico-ecosistema-de-hadoop

Salazar, Argonza Javier, "Infraestructura para Big Data”. Revista Digital Universitaria, 1 de noviembre de 2016, Vol. 17, Núm. 11. Disponible en Internet: http://www.revista.unam.mx/vol.17/num11/art7 $7 /$

SAS (s. f.). ¿Qué es Hadoop? Recuperado 24 de febrero 2021 de https://www.sas.com/es_mx/insights/bigdata/hadoop.html 